\title{
The Other Side of the Story: Greenhouse and Nursery Producers' Perceptions about Neonicotinoid Insecticides and Pollinator Friendly Labeling ${ }^{1}$
}

\author{
Hayk Khachatryan, Xuan Wei, and Alicia Rihn²
}

\section{Introduction}

This article summarizes producers' perceptions about neonicotinoid insecticide labeling required for ornamental plants, as well as the potential changes in production practices due to the new labeling policy requirement. It is important for Extension agents to understand producers' opinions while transferring knowledge and making more relevant research recommendations. The target audience includes industry, state agency, and public stakeholders involved in decisions and policy making related to the use of neonicotinoid insecticides (sometimes called "neonics") in the US ornamental plants industry. The contents could be used as reference point for firms interested in considering production and labeling decisions toward neonicotinoid insecticides and considering the first-mover advantage in response to consumers' preference. Policymakers may consider policy interventions with less friction. Increasing public awareness and encouraging consumers to change shopping behaviors by selecting products produced using sustainable practices has the potential to reduce friction.

\section{Background}

The ornamental horticulture industry provides important economic contributions to the US agricultural sector. The 2018 US Green Industry economic impacts (including indirect and induced effects in other sectors) were estimated at $\$ 348$ billion in output or revenues and 2.32 million total jobs (Hodges et al. 2019). In recent years, greenhouse and nursery producers in the ornamental horticulture industry have experienced diminishing revenue and shrinking profit margins due to considerable within-industry consolidation, increased competition, and relatively weak consumer demand (Madigan 2018). The industry's average annual sales revenue was about $\$ 1.39$ million per firm in 2018 (Khachatryan et al. 2020) compared to 1.83 million in 2013 (Hodges et al. 2015). Meanwhile, a recent trend to impose more restrictive labeling polices by retail stores on pesticide use (i.e., disclosing the use of neonicotinoids) may impact producers' production costs further. Maintaining low-cost and competitive production practices thus has become increasingly important for nursery and greenhouse producers to stay profitable.

Due to concerns about neonicotinoids' negative impact on pollinator health, EU regulators banned the use of three major neonicotinoids in 2013 (Fairbrother et al. 2014). The US EPA was more cautious toward restricting the use of neonicotinoids and now requires neonic-containing products to have a warning label indicating proper usage to minimize harm to pollinators. Meanwhile, several large retailers have required labeling of the use of neonicotinoid

1. This document is FE1094, one of a series of the Food and Resource Economics Department, UF/IFAS Extension. Original publication date March 2021. Visit the EDIS website at https://edis.ifas.ufl.edu for the currently supported version of this publication.

2. Hayk Khachatryan, associate professor and Extension economist, Food and Resource Economics Department; Xuan Wei, postdoctoral researcher; and Alicia Rhin, postdoctoral research associate; Food and Resource Economics Department, UF/IFAS Mid-Florida Research and Education Center, Apopka, FL.

The Institute of Food and Agricultural Sciences (IFAS) is an Equal Opportunity Institution authorized to provide research, educational information and other services

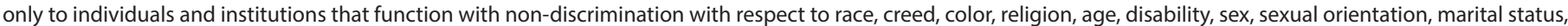

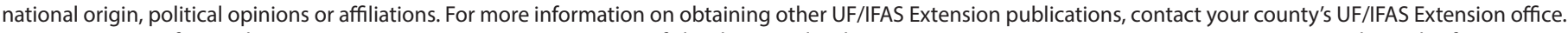
U.S. Department of Agriculture, UF/IFAS Extension Service, University of Florida, IFAS, Florida A \& M University Cooperative Extension Program, and Boards of County Commissioners Cooperating. Nick T. Place, dean for UF/IFAS Extension. 
pesticides in plant production. While consumers express increasing preferences for and perceptions of ornamental production practices that aid pollinator insects (Getter et al. 2016; Khachatryan and Rihn 2017; Rihn and Khachatryan 2016; Wollaeger et al. 2015;), a holistic assessment of policies concerning the use of neonicotinoids and neonicotinoids labeling should also consider potential impact faced by the ornamental plant producers.

To investigate the use of neonicotinoid insecticides in the ornamental plants industry and producers' perceptions of insecticide labeling, we conducted a national survey. Internet and mail survey options were used to collect a representative nationwide sample. The internet survey (conducted from August to December, 2018), was distributed through horticultural industry associations' member lists and trade magazine websites (e.g., Florida Nursery, Landscaping and Growers Association, Nursery Management magazine, and Greenhouse Grower magazine). One hundred sixty four producers from 49 states completed the internet survey. Following the internet survey distribution, 3000 printed surveys were mailed to randomly selected producers. The industry firm contact lists were obtained from the Dun \& Bradstreet database. Twelve states including California, Florida, Hawaii, Illinois, Maryland, New Jersey, New York, North Carolina, Ohio, Pennsylvania, Texas, and Washington were selected based on the USDA 15-state data collection program that includes major ornamental production states. Tennessee, North Dakota, Wisconsin and Vermont were selected to represent other miscellaneous production states. The number of producers responding to the mail survey was 260 , representing less than 10 percent response rate. It is important to note that a low survey response rate is typical for producer surveys. (Dennis et al. (2010), for example, reported a response rate of $12 \%$. Hodge et al. (2015) reported a response rate of $8 \%$.) After excluding small-scale producers employing less than five employees and surveys with missing responses to a large number of questions, 166 responses were used in the final sample. This article used responses from 86 internet and 80 mail survey participants (Table 1). The distribution of the 166 producers by primary location of business is summarized in Table 2. As expected, California and Florida have the highest number of responses given the size of the ornamental plants industry relative to other states.

\section{Production Practices and Market Channels Used}

Among the 166 producers, 52 (32\%) were operating in greenhouses, 46 (28\%) were operating in open field or container systems, and 67 producers (41\%) reported both types of operations. The average production area was 1.2 million (M) square feet for greenhouse operations and 81.2 acres for open field or container operations. Despite the low response rate and small sample size, the sampled firms are representative of the industry. Among the responses, 124 firms reported their annual sales values prior to the survey year. Twenty three percent of the firms reported their annual sales as less than $\$ 250,000$. A large number of the respondents were medium-sized firms: 55\% reported annual sales between $\$ 250,000$ and $\$ 10,000,000$. Only $16 \%$ of firms reported annual sales larger than $\$ 10,000,000$. Average sales value by production type is summarized in Figure 1. Compared with open field or container production, greenhouse producers reported higher annual sales.

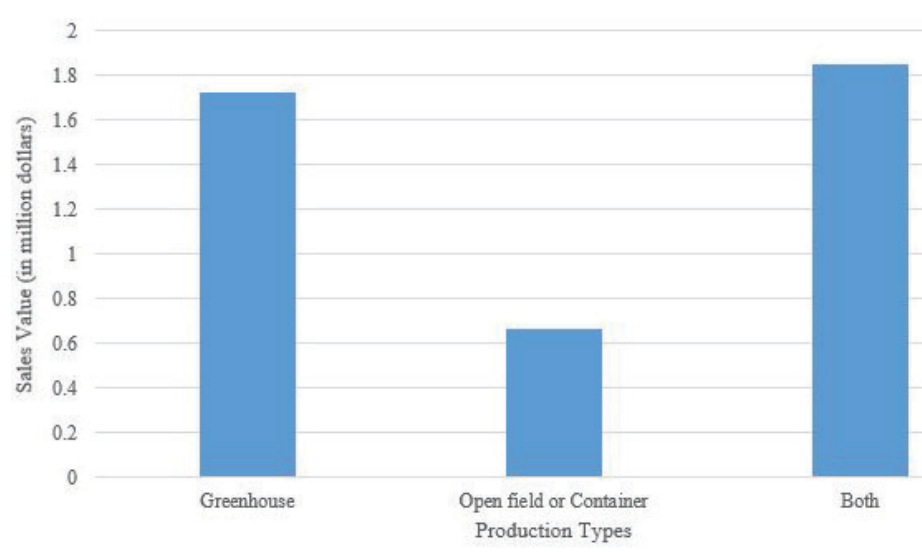

Figure 1. Average annual sales value by production types.

Respondents also specified the distribution of total sales value to different market outlets, including mass merchandisers (e.g., general merchandise stores), home centers, single-location garden centers, multiple-location garden centers, landscape firms, re-wholesalers (brokers, other growers, etc.), wholesale direct to farmers, and retail direct to consumer (Figure 2). The most popular outlet (as a share of total sales) was landscape firms, representing 42 percent of sales, followed by re-wholesalers and wholesale direct to farmers (34\% each), single-location garden centers (32\%), retail direct to consumer (27\%), multiple-location garden centers (19\%), home centers (13\%), and mass merchandisers $(8 \%)$. 


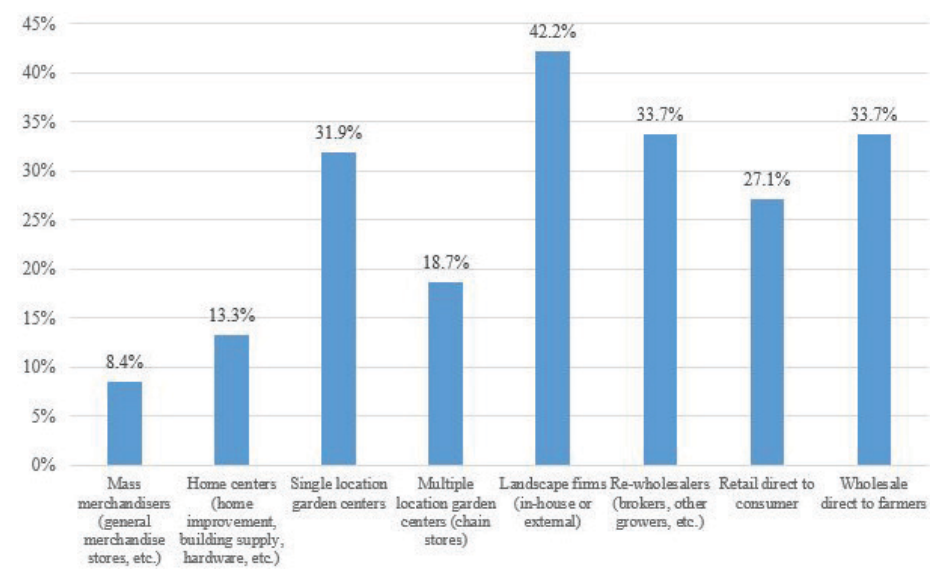

Figure 2. Distribution of annual sales value by market channels.

\section{Perceptions about Neonicotinoid Insecticides and Labeling Preferences}

When asked about their perceptions regarding the effectiveness of neonicotinoid insecticides, surveyed growers agreed that neonicotinoid insecticides were effective tools to protect plants from major pests, with a mean rating score of 6 out of 7 (Figure 3). With regard to the statement whether they are concerned about the effect of neonicotinoid pesticides on pollinators, the average rating is about 5 (slightly agree) out of 7 , indicating some concerns about the effects of neonicotinoid insecticides. On the other hand, when asked whether they would be willing to accept a $10 \%$ cost increase to promote neonicotinoid-free pesticides, they showed some reluctance (with a mean rating of 4 indicating neither agree nor disagree to cost increase).

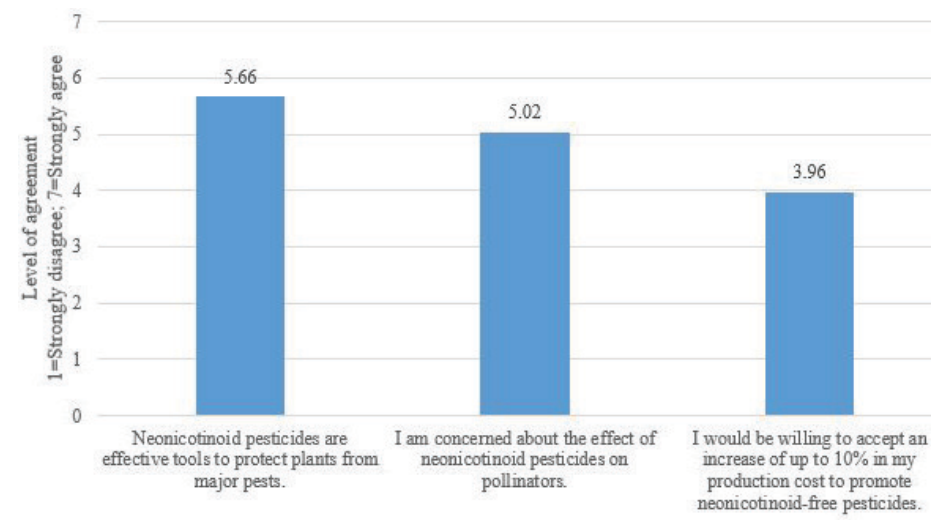

Figure 3. Producers' perceptions about neonicotinoid insecticides and pollinators.

The survey participants were also asked to express their opinions about a policy requiring mandatory labeling of neonicotinoids based on their own experiences. Out of 124 respondents, 52.4 percent opposed a mandatory labeling of neonicotinoids policy (Figure 4). This is understandable because 70 out of 166 growers (42\%) clearly indicated that they currently use neonicotinoids. Twenty percent of the growers had a neutral position regarding a mandatory labeling policy (4). In contrast, 28 percent of the growers expressed agreement about the mandatory labeling policy. On average, participating producers were less supportive of mandatory labeling of neonicotinoids as compared with consumers. Interested readers may refer to Khachatryan et al. 2020a for more detailed information on the consumer side.

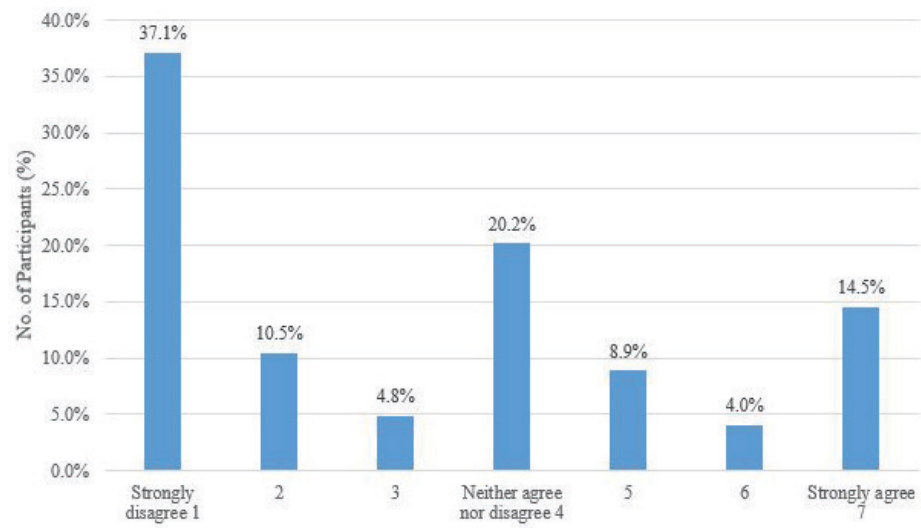

Figure 4. Producers' perceptions about mandatory neonicotinoid labeling policies

Producers were further asked to rate their level of agreement or disagreement about the potential benefits/costs of neonicotinoid labeling. The survey used a 7-point rating scale with 1 indicating strongly disagree and 7 strongly agree. As shown in Figure 5, surveyed producers generally agreed labeling plants treated with neonicotinoids would increase growers' costs (with a mean rating of 5.2). They also expressed less agreement toward consumers being willing to pay a price premium for plants with neonicotinoidfree labeling (with a mean rating of 3.8).

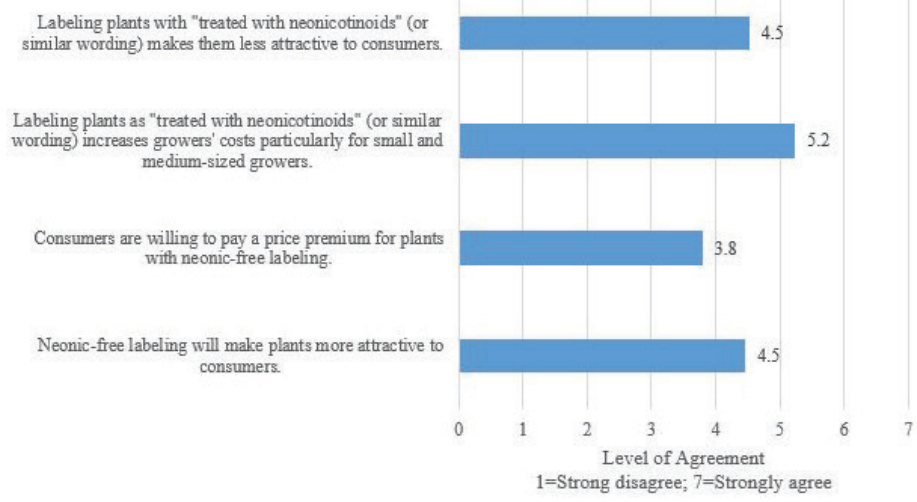

Figure 5. Producers' perceptions about benefits and costs of neonicotinoid labeling.

Surveyed producers selected the top three most attractive labeling phrases indicating pollinator friendly production practices from a given list including "Pollinator attractive," "Pollinator friendly," "Bee attractive," "Bee friendly," "Bee safe," " Butterfly friendly," "Butterfly attractive," "Neonicfree," "Pollinator safe," "Butterfly logo/image," "Bee logo/ 
image," and "Plants for pollinators." The top three most attractive labeling phrases were "Pollinator friendly" (36\%), "Pollinator safe" (30\%) and "Bee friendly" (26\%). The three least attractive labeling phrases were "Bee attractive" (3\%), "Pollinator attractive" (8\%), and "Butterfly attractive" (10\%) (Figure 6). Comparing the individual key words in the most and least attractive labeling phrases, producers were clearly more in favor of "friendly" and "safe" than the word "attractive."

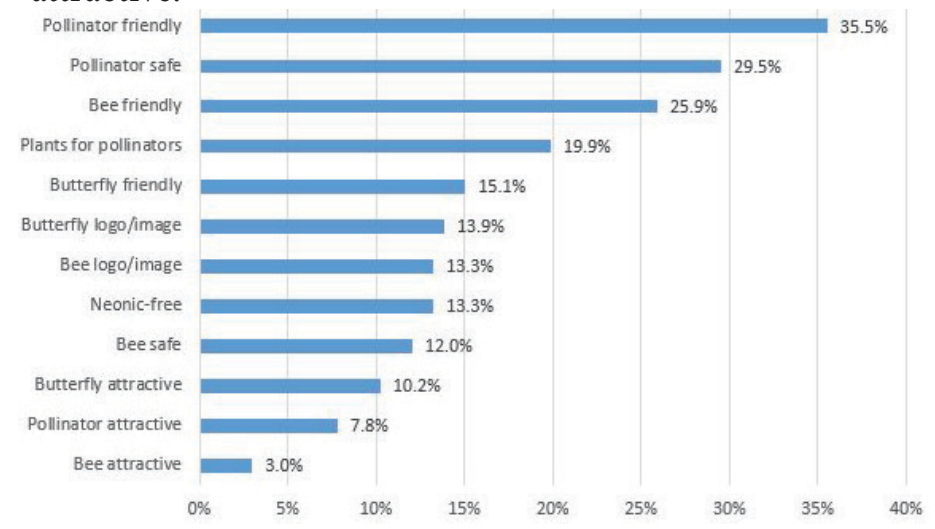

Figure 6. Producers' perceptions about most effective pollinatorrelated labeling phrases.

\section{Anticipated Changes in Input Costs and Yields}

Producers were asked to indicate whether they anticipated any changes in their input costs if neonicotinoids could not be used. The majority of the producers who answered this question believed eliminating the use of neonicotinoid insecticides would not reduce their costs (Table 3).This may be attributable to the fact that, at the time the survey was taken, 66 producers (40\%) did not use neonicotinoids. Yet, among all input cost items, producers showed more concerns about increased pesticides and labor costs. Thirty five percent of producers anticipated increases in pesticide costs, 29 percent anticipated increased costs in unskilled labor, and 22 percent expected increases in skilled/ managerial labor cost (Figure 7). Only a few respondents anticipated decreases in pesticides and labor costs. Further, 92 producers (i.e., $55 \%$ of a total of 166 participating producers) provided predictions on yield changes if neonicotinoid insecticides could not be used in their pest management programs. Forty producers (24\%) anticipated decreases in yield, 34 (20\%) anticipated no changes in yield, and $18(11 \%)$ anticipated increases in yield.

\section{Conclusion}

Most recent studies have revealed that the EU's ban on neonicotinoids has caused a yield decrease (Dewar 2016; Noleppa 2017) and increase of production costs (Noleppa 2017) in oilseed rape production in European countries.
Banning neonicotinoids has forced farmers to use alternative means of pest control, which may have unintended consequences such as pest resistance (Bass and Field 2018). Jactel et al. (2019) showed that the most common alternative to neonicotinoid insecticides is another chemical insecticide ( $89 \%$ of cases). Other insecticides producers use when neonicotinoids are banned are not necessarily safer for the environment than the neonicotinoids.

In the United States, garden centers increasingly require labels indicating the use of neonicotinoid insecticides in ornamental plant production. Meanwhile, even though increasing numbers of consumers pursue a "greener" gardening approach by decreasing or eliminating the use of pesticides, many consumers are not familiar with neonicotinoid insecticides. There is a significant knowledge gap between consumers' stated knowledge (what they think they know) and actual knowledge (what they actually know) about pollinator attractive plants (Khachatryan et al. 2020a). Further, there is a considerable difference between producer vs. consumer preferences for labeling practices (Khachatryan et al. 2020b). As reported in this publication, the information could be useful for relevant industry/ agency stakeholders in shaping socially optimal policies related to the use of neonicotinoid insecticides, including labeling policies.

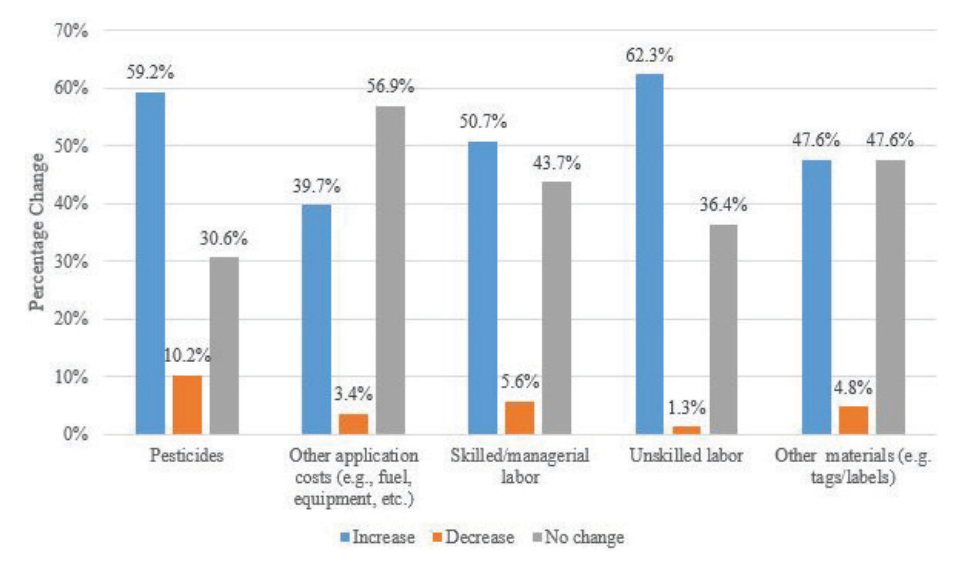

Figure 7. Producers' perceptions about most effective pollinatorrelated labeling phrases.

\section{References}

Bass, C., and L. M. Field. 2018. "Neonicotinoids." Current Biology 28 R761-R783.

Dewar, A. M. 2016. “The Adverse Impact of the Neonicotinoid Seed Treatment Ban on Crop Protection in Oilseed Rape in the United Kingdom." Pest Management Science 73 (7): 1305-1309. 
Getter, K. L., B. K. Behe, and H. M. Wollaeger. 2016. "Comparative Consumer Perspectives on Eco-Friendly and Insect Management Practices on Floriculture Crops." HortTechnology 264653.

Hodges, A. W., H. Khachatryan, C. R. Hall, and M. A. Palma. 2015. Production and Marketing Practices and Trade Flows in the United States Green Industry, 2013. Southern Cooperative Series Bulletin \#420, May 2015.

Hodges, A. W., H. Khachatryan, C. R. Hall, and M. A. Palma. 2019. "Executive Summary of Economic Contributions of the Green Industries in the United States in 2018." AmericanHort.

Jactel, H., F. Verheggen, D. Thiéry, A. J. Escobar-Gutiérrez, E. Gachet, N. Desneux, and the Neonicotinoids Working Group. "Alternatives to Neonicotinoids." 2019. Environmental International 129:423-429.

Khachatryan, H., and A. Rihn. 2017. "Consumer Perceptions of Plant Production Practices that Aid Pollinator Insects' Health." HortScience 52749755.

Khachatryan, H., X. Wei, and A. Rihn. 2020a. Are Consumers Knowledgeable about Neonicotinoid Insecticides and Pollinator Friendly Plants? FE1081. Gainesville: University of Florida Institute of Food and Agricultural Sciences. https://edis.ifas.ufl.edu/fe1081

Khachatryan, H., Hodges, A. W., C. R. Hall, and M. A. Palma. 2020. Production and Marketing Practices and Trade Flows in the United States Green Industry, 2018. Southern Cooperative Series Bulletin \#420, May 2020.

Khachatryan, H., X. Wei, and A. Rihn. 2020b. Consumer and Producer Perceptions and Preferences for Pollinator Friendly Labeling Practices in the US Green Industry. FE1093. Gainesville: University of Florida Institute of Food and Agricultural Sciences. https://edis.ifas.ufl.edu/fe1083

Madigan, J. 2018. Plant \& flower growing in the US. IBISWorld Industry Report 11142.

Noleppa, S. 2017. Banning Neonicotinoids in the European Union: An Ex-Post Assessment of Economic and Environmental Costs. HFFA Research Paper 01/2017.
Rihn, A., and H. Khachatryan. 2016. "Does consumer awareness of neonicotinoid pesticides influence their preferences for plants?" HortScience 51:388-393.

Wollaeger, H. M., K. L.Getter, and B. K. Behe. 2015. "Consumer Preferences for Traditional, NeonicotinoidFree, Bee-friendly, or Biological Control Pest Management Practices on Floriculture Crops.” HortScience 50721732. 
Table 1. Number of respondents by survey type.

\begin{tabular}{|c|c|c|c|}
\hline Survey type & Total number of respondents & $\begin{array}{c}\text { Number of respondents } \\
\text { included in the study }\end{array}$ & Percentage (\%) \\
\hline Internet & 164 & 86 & $(52)$ \\
\hline Mail & 260 & 80 & $(48)$ \\
\hline Total & 424 & 166 & $(100)$ \\
\hline
\end{tabular}

Table 2. Distribution of respondents by primary location of business.

\begin{tabular}{|c|c|c|c|c|c|}
\hline State & Frequency & (\%) & State & Frequency & $(\%)$ \\
\hline Alabama & 3 & (1.8) & Montana & 1 & (0.6) \\
\hline Arkansas & 1 & $(0.6)$ & Nebraska & 4 & $(2.4)$ \\
\hline California & 24 & $(14.5)$ & New Jersey & 4 & (2.4) \\
\hline Colorado & 2 & $(1.2)$ & New York & 2 & (1.2) \\
\hline Connecticut & 1 & $(0.6)$ & North Carolina & 11 & (6.6) \\
\hline Florida & 21 & (12.7) & North Dakota & 3 & (1.8) \\
\hline Georgia & 1 & $(0.6)$ & Ohio & 9 & (5.4) \\
\hline Idaho & 1 & $(0.6)$ & Oklahoma & 1 & $(0.6)$ \\
\hline Illinois & 5 & (3.0) & Oregon & 2 & $(1.2)$ \\
\hline Indiana & 1 & $(0.6)$ & Pennsylvania & 11 & (6.6) \\
\hline lowa & 2 & $(1.2)$ & South Carolina & 1 & $(0.6)$ \\
\hline Kansas & 1 & $(0.6)$ & South Dakota & 2 & $(1.2)$ \\
\hline Louisiana & 1 & $(0.6)$ & Tennessee & 5 & (3.0) \\
\hline Maine & 1 & $(0.6)$ & Texas & 13 & (7.8) \\
\hline Maryland & 6 & (3.6) & Utah & 1 & $(0.6)$ \\
\hline Massachusetts & 1 & $(0.6)$ & Vermont & 3 & (1.8) \\
\hline Michigan & 4 & (2.4) & Virginia & 3 & (1.8) \\
\hline Minnesota & 2 & $(1.2)$ & Washington & 4 & (2.4) \\
\hline Mississippi & 1 & $(0.6)$ & Wisconsin & 6 & (3.6) \\
\hline Missouri & 1 & $(0.6)$ & Total & 166 & $(100)$ \\
\hline
\end{tabular}

Table 3. Number of producers anticipating positive, negative, or no change in input costs.

\begin{tabular}{|c|c|c|c|c|c|c|c|c|}
\hline Input Items & $\begin{array}{l}\text { No. of } \\
\text { Producers }^{\mathrm{a}}\end{array}$ & $(\%)^{b}$ & $\begin{array}{l}\text { Positive } \\
\text { change }\end{array}$ & $(\%)^{b}$ & $\begin{array}{l}\text { Negative } \\
\text { change }\end{array}$ & $(\%)^{b}$ & $\begin{array}{c}\text { No } \\
\text { change }\end{array}$ & $(\%)^{b}$ \\
\hline Pesticides & 98 & (59) & 58 & (35) & 10 & (6) & 30 & (18) \\
\hline $\begin{array}{l}\text { Other application costs } \\
\text { (e.g., fuel, equipment, } \\
\text { etc.) }\end{array}$ & 58 & (35) & 23 & (14) & 2 & (1) & 33 & (20) \\
\hline Skilled/managerial labor & 71 & $(43)$ & 36 & $(22)$ & 4 & $(2)$ & 31 & (19) \\
\hline Unskilled labor & 77 & $(46)$ & 48 & (29) & 1 & (1) & 28 & (17) \\
\hline $\begin{array}{l}\text { Other materials (e.g. } \\
\text { tags/labels) }\end{array}$ & 63 & (38) & 30 & $(18)$ & 3 & (2) & 30 & (18) \\
\hline
\end{tabular}

